Wioletta Krawiec

\title{
Kultura obrazka a zaangażowanie konsumenta w proces budowania marki na przykladzie portalu społecznościowego Pinterest
}

Rozwój Internetu doprowadził do łatwego dostępu do informacji, ale również przyczynił się do jej powstawania. Każdego dnia jesteśmy „bombardowani” informacją, której nie jesteśmy w stanie przetworzyć. Dlatego też w naturalny sposób zaistniała potrzeba uporządkowania i skrócenia procesu przyswajania informacji w jasny, przejrzysty, a głównie szybki sposób. Kultura obrazka okazała się wybawieniem w powstałych okolicznościach i stała się przyczyną zmiany przekazu informacji, budowania marki czy komunikacji, która rozpowszechniana jest zarówno w tradycyjnych, jak i nowoczesnych nośnikach informacji. Zatem zmiana chociażby designu strony www, elektroniczna komunikacja, mocniejsza ekspozycja elementów wizualnych, wykorzystywanie infografiki, videostorytellingu, rozwój platform o naturze obrazkowej stanowią w dzisiejszych czasach najważniejsze działania menedżerów, którym zależy głównie na zainteresowaniu i zatrzymaniu konsumenta przy marce firmy.

Podkreślenie znaczenia rozwijającej się kultury obrazkowej w procesie budowania marki oraz zaangażowania klienta $\mathrm{w}$ proces jej kreowania na podstawie portalu społecznościowego Pinterest to zagadnienia podjęte w niniejszym artykule.

\section{Infografika - jej korzenie i siła we współczesnym świecie}

Najprościej rzecz ujmując, infografika jest to przystępna i przejrzysta graficzna prezentacja danych, informacji i wiedzy. Infografika jest najbardziej udanym związkiem słowa z obrazem. Według czasopisma „Digit” infografika mieści się w każdym rodzaju grafiki, który wspiera bądź przekazuje informacje, a więc zarówno prosty wykres ze słupkami, jak i interaktywny przewodnik po muzeum. J. Casserta, projektant, którego prace zamieszczają „New York Times” i „National Geographic”, uważa, że bardziej precyzyjny byłby termin „grafika objaśniająca”, 
bo kładzie on nacisk nie na informowanie, ale raczej samo graficzne wyjaśnienie informacji.

Zamiłowanie do obrazka nie jest niczym nowym. Już w średniowieczu korzystano z obrazu (rysunku, ikon), aby przekazać czy przyswoić wiedzę religijną. W wieku XVIII W. Playfair wykorzystywał infografikę do wizualizacji danych statystycznych w postaci słupków, linii, koła itp.

Natomiast $w$ latach trzydziestych XX wieku infografika przeszła swój rozkwit, związany z czasopismem „Today” w USA, które zaczęło umieszczać wizualizację na swoich łamach. Zatem kultura obrazka istnieje od wieków, natomiast z rozwojem Internetu, a głównie Google, social media, nabierała większego znaczenia. Największy boom obrazka nastąpił jednak wraz z pojawieniem się tzw. zjawiska infotainmentu (informacja, rozrywka), którego zadaniem jest przekazywać informacje, ale w zabawny sposób. Dziś miliardy informacji dziennie, udostępniane chociażby na Facebooku, przyjmują postać zdjęcia, memu i infografiki. Zatem nic dziwnego, że w zabieganym świecie, w natłoku informacji obraz stał się najbardziej wygodnym narzędziem przekazu informacji, natomiast nowe technologie umożliwią ich rozprzestrzenianie.

\section{Kultura obrazka a współczesny klient w kreowaniu marki}

Problemem, przed jakim staje dzisiejsza firma, jest trudność przykucia uwagi konsumenta, a jeszcze bardziej zatrzymania go na dłużej, przy jednoczesnym angażowaniu go we współtworzenie wizerunku marki.

Należy zauważyć, że obecny klient w natłoku różnych informacji nie czyta, lecz skanuje treści. Infografika zatem otwiera drogę do nawiązania relacji z klientem w nieco inny sposób niż dotychczas. Nowym zjawiskiem jest zmieniający się stosunek komunikacji tekstowej do obrazkowej. W praktyce oznacza to, że nie obrazek wspiera tekst, lecz tekst uzupełnia obrazek. Odnosząc to zjawisko do procesu zakupu online klient kiedyś rozpoczynał swoje poszukiwania od zapytania w wyszukiwarce. Początkowo produktu samego w sobie, następnie zawężając poszukiwania do marki produktu. Wraz z rozwojem komunikacji oraz zwiększaniem się natłoku informacji klient ostateczne nie wyszukuje kategorii produktu, ani marki, tylko w sieci zaczął szukać inspiracji. Natomiast aspekt poszukiwania inspiracji, doznań przez obecnego konsumenta wymusza na firmie szukania sposobów, które zaangażują klienta również do budowania percepcji marki przez jego osobiste działania. Ten sposób podejścia do kreowania marki wpisuje się w nowy nurt, tzn. marketing doświadczeń, w którego obrębie konsument chce nabywać 
przede wszystkim doznania (doświadczenia) w procesie poznawania i kreowania. Podejście to pozwala budować więzi osobiste między konsumentem a firmą czy marką ${ }^{1}$. Marketing doświadczeń jest nieco szerszym i głębszym pojęciem, natomiast odniesienie się w tym artykule do jego korzeni stanowi jedynie źródło podkreślenia siły oddziaływania przedsiębiorstwa na konsumentów poprzez różnego rodzaju wydarzenia, podczas których np. konkursy, zadania, gry są wykorzystywane jako nośniki budowania doznań i relacji z konsumentami. Tego typu zachowania konsumenta możemy zaobserwować na portalu społecznościowym Pinterest ${ }^{2}$. Pokazał on jak prowadzić skuteczną komunikację z dzisiejszym konsumentem. W kontekście zmiany jego zachowań ten sposób stał się wręcz podstawą $\mathrm{w}$ procesie budowania marki w środowisku wirtualnym. Zachował jednak podstawową zasadę budowania marki w Internecie - marka w Internecie ma mieć twarz, a nie „gębę”. Konsument ma ją postrzegać jak znajomego, przyjaciela, a najlepiej byłoby gdyby się w niej zakochał i chciał żyć z nią do przysłowiowej "grobowej deski"3.

Zatem marka musi budzić emocje (doznania), chęci utrzymywania z nią więzi, odczuwania przynależności, aby mogła zaangażować społeczność w proces kreowania swojej „ukochanej” marki.

\section{Pinterest a kreowanie marki}

Pinterest jest siecią społecznościowego wizualnego odkrywania. Przypomina wirtualną wersję tablicy korkowej, na której przypinamy (pin - przypinać) zdjęcia, notatki, filmy, które nam się spodobały lub do czegoś zainspirowały. Tworzone internetowe tablice informacyjne dla różnych kategorii (np. „dom marzeń”, „rzeczy do kupienia” czy „przepisy”), mają być inspiracją dla jego użytkowników, miejscem analizy marki w nieco bardziej kreatywny sposób niż dotychczas.

Pinterest może być idealnym miejscem budowania marki, pogłębiania jej postrzegania wśród obecnych i potencjalnych konsumentów, również jest to dobre miejsce na budowanie relacji w obrębie fanów marki. Pinterest zdecydowanie nie jest platformą dla samopromocji i transmitowania treści promocyjnych w stylu Facebooka czy Twittera. Chcąc na nim być, marki muszą być kreowane w odmienny sposób, do tego mogą być przydatne poniższe wskazówki

${ }^{1}$ B.H. Schmidt, Experiential Marketing, ,Journal of Marketing Management” 1999, No 15.

2 A. Dymkowska, Promocja tadna jak z obrazka, „Marketing w Praktyce” 2012, nr 11, s. 20-22.

3 A. Ries, L. Ries, 11 praw budowania marek internetowych, IFC Press, Warszawa 2001, s. 10.

${ }^{4}$ Raport: Pinterest nowym narzędziem marketingowym, www.oxmedia.pl [dostęp: 5.01.2013]; 5 porad dla marek na Pinterest, http://social24.pl/5-porad-dla-marek-na-pinterest/ 
- Odpowiedz, jaki styl życia jest domeną twojej marki. Bycie na portalu Pinterest ma sens wówczas, gdy za marką stoi idea. Ponieważ nie powinno się umieszczać zdjęć produktów na portalu, należy myśleć nieszablonowo i zamieszczać obrazki, które odzwierciedlają styl życia firmy i esencje marki firmy. Kompleksowe podejścia do marketingu na Pintereście może być bardziej efektywne niż tradycyjna reklama. Konsumenci mogą utożsamiać się z marką i traktować ją jak przyjaciela, który stanowi część ich życia.

- Zarządzaj szerokim zakresem tablic luźno powiązanych z produktami firmy. Pinterest umożliwia umieszczanie wielu tablic informacyjnych. Użytkownicy mogą zainteresować się jedną, kilkoma lub wszystkimi. Zarządzanie szerokim zakresem tablic w różnych kategoriach pozwoli większej liczbie użytkowników poznać markę.

- Analizuj zachowanie użytkowników. Użytkownicy Pinterestu zazwyczaj śledzą przedmioty, które kochają, miejsca, które lubią, jedzenie, które konsumują i rzeczy, które ich inspirują. Dlatego też można traktować ich jak grupy fokusowe. Jeżeli interesują się marką firmy daje to podstawę do prowadzenia analizy tego, co przyczepiają i kogo jeszcze śledzą. Użytkownicy w ten sposób zdradzają wiele informacji o sobie. Informacje te pozwalają zgłębić wiedzę na temat własnej grupy docelowej.

- Pozwól konsumentom umieszczać własne informacje. Umożliwienie fanom (konsumentom) przypięcia zdjęć, na których pozują razem z ulubionym produktem (stworzonym przez firmę), przyczyni się do pokazania potencjalnym klientom, że obecni konsumenci naprawdę lubią używać tych produktów.

- Organizuj konkursy. Organizowanie konkursów pozwala zaangażować społeczność i przytrzymać ja na dłużej. Proces angażowania thumu jest niezwykle ważny w świecie, w którym konsument szuka inspiracji, zabawy, możliwości wykazania się. Proces angażowania daje również możliwość budowania więzi z innymi uczestnikami konkursu, którzy obserwując swoje działania w naturalny sposób są motywowani do bardziej kreatywnej pracy.

- Pokaż, co inspiruje twoją markę. Opracuj tablicę inspiracji dla własnej firmy i przyczepiaj rzeczy, które są ważne, interesujące lub inspirujące firmę bądź pracowników firmy. Zamieszczaj loga i dobrze zaprojektowane strony internetowe, dobrze przemyślane hasła reklamowe, zdjęcia członków załogi itp.

- Używaj oryginalnych zdjęć. Umieszczanie własnoręcznie wykonanych zdjęć i oryginalnych obrazków wywołuje większe zainteresowanie nimi i przypinanie ich do swoich tablic, co może wygenerować spory ruch wokół profilu firmy.

[dostęp: 12.04.2012]; Jak używać Pinterest do wsparcia biznesu, http://www.conceptinteractive.pl/ jak-uzywac-pinterest-do-wsparcia-biznesu,blog,50,11,pl [dostęp: 15.05.2012]. 
- Opracuj katalogi. Stwórz pinboard i przyczepiaj obrazki oparte na jednej z twoich kolekcji. Takie działanie przyciąga do profilu firmy osoby naprawdę zainteresowane kupnem przyczepionego produktu.

\section{Pinterest - jego siła oddziaływana i kogo tam można spotkać?}

Pinterest łączy cechy wszystkich dotychczasowych portali społecznościowych, tzn. dużą interaktywność, budowanie własnej społeczności, możliwość komentowania i lubienia. To, co go odróżnia od innych, to życie społeczności w kulturze obrazka. Jak żaden inny z dotychczasowych portali społecznościowych koncentruje się na zainteresowaniach użytkowników. Każdy może pokazać swoje pasje, styl życia, ulubione postawy czy zdjęcia z wakacji. Badania przeprowadzone przez comScore pokazują, że użytkownicy spędzają na portalu średnio 89 minut w ciągu miesiąca. W porównaniu z innymi portalami społecznymi jest to 4 do 29 razy więcej niż na innych portalach, takich jak Twitter czy Google ${ }^{5}$. Badania przeprowadzone przez Shareaholic ujawnily, że Pinterest odsyła na inne witryny więcej ruchu niż Twitter, Google+, LinkedIn oraz YouTube. Pinterest ma już ponad 17 milionów użytkowników. W porównaniu z gigantami, Facebookiem, Twitterem czy MySpace to wciąż niewiele. Warto jednak zauważyć, że Pinterest rośnie dużo szybciej niż Twitter, który po dwóch latach funkcjonowania zgromadził 6 milionów użytkowników. Polskich użytkowników z każdym dniem również przybywa. Wyniki badań Megapanelu dowodzą, że w kwietniu 2012 r. Pinterest odwiedziło ponad 290 tys. realnych użytkowników ${ }^{6}$. Wyniki z badań comScore, Shop.org i Partnering Group z maja 2012 r. pokazują, że użytkownik Pinterest obserwuje średnio 9,3 stron firmowych, podczas gdy, dla porównania, na Facebooku liczba ta wynosi 6,9. Z kolei z sondażu Steelhouse wynika, że 59\% użytkowników Pinterest kupiło produkt pod wpływem reklamy w serwisie. W przypadku Facebooka odsetek ten wyniósł $33 \%$.

Ciekawym zjawiskiem jest fakt, że głównymi użytkownikami Pinerestu są kobiety. Stanowią one wg różnych źródeł 60-80\% klientów w przedziale wiekowym 25-54 lata $(81 \%)^{7}$. Jest to istotna informacja dla firm, z której skorzystała m.in. pierwsza z polskich marek na Pintereście - Winiary. Grupą docelową marki

\footnotetext{
${ }^{5}$ Raport: Pinterest nowym narzędziem marketingowym, www.oxmedia.pl [dostęp: 5.01.2013].

${ }^{6}$ B. Ratuszniak, Pinterest jak Facebook. Rośnie w Polsce równie szybko, http://interaktywnie. com/biznes/artykuly/social-media/pinterest-jak-facebook-rosnie-w-polsce-rownie-szybko-23730 [dostęp 26.06.2012].

${ }_{7}$ M. Małecki, Pinterest - czy polskie marki maja tu czego szukać?, http://nowymarketing. pl/a/28, pinterest-czy-polskie-marki-maja-tu-czego-szukac [dostęp: 16.05.2012].
} 
WINIARY są przede wszystkim kobiety, więc z punktu widzenia celów marki, jej grupy docelowej oraz przygotowanej strategii na działania w social media wejście na Pinteresta było czymś zupełnie naturalnym.

\section{Polska marka na Pintereście}

Wzrost potencjału portalu Pinterest jest tak duży, że należy na bieżąco śledzić kampanie realizowane zarówno dla światowych, jak i krajowych marek. Polskie marki dopiero zaczynają działać w tym portalu, więc też firmy, które w chwili obecnej zdecydują się na wdrożenie go do działań w obrębie budowania wizerunku firmy mogą wiele zyskać. Zgodnie z zasadą „,kto pierwszy ten lepszy” oraz dzięki skutecznym działaniom PR-owym, firmy mogą również sprawić, że o marce będzie głośno w innych mediach, m.in. na FB, Twitterze, Google ${ }^{8}$. Poniżej podano firmy, które już istnieją na Pintereście i których udział z każdy dniem jest silniejszy. O ich sile świadczą chociażby przyłączające się osoby, jako „śledzące” daną markę (firmę) czy też fani danej ,tablicy” na profilu firmy.

Do pierwszych polskich marek, które postanowiły zaistnieć na Pintereście należą m.in. takie firmy, jak HBO Polska (197 osób śledzi jego profil), Winiary (285) czy Polskie Linie Lotnicze LOT (401). Na Pintereście spotkać można farby Magnat (211), Mokate, Kasię, Hortex, Grupę PZU. Obserwować możemy także marki o zasięgu globalnym, takie jak EMI Music Poland, EuroFlorist Polska, Gorenje Polska, Hellmann's, Olympus Polska, Pioneer Polska, Toyota Polska i Virgin Mobile Polska. Ponadto Pinterestem zainteresowali się również przedstawiciele mediów. Najchętniej śledzonymi kontami są: InStyle Polska (220), Newsweek Polska (537). Konta na Pintereście założyły: Radio Złote Przeboje, Radio RMF FM, Eska, MTV Polska, VIVA Polska, SportUp.tv, Forbes Polska, Top Gear Polska oraz serwisy internetowe NaSzpilkach, Polki.pl, Pudelek i Onet Gotowanie. W tematyce moda, uroda i styl życia króluje zyciewluksusie.pl. Obserwowane jest przez 1386 osób, a konta założyły również: Aryton, Gocco Polska, Great Lengths Poland, Funk'n'Soul Fashion, Lee Cooper Polska i NeoNail Poland. Ich znaczenie jest jednak dużo mniejsze. Wśród kont sklepów internetowych największą popularnością cieszą się sklep sprzedający buty Deezee.pl (544 obserwujących), SHOWROOM, platforma internetowa, która została stworzona, aby objąć niezależnych projektantów mody i nie tylko, gdyż zapewnia przestrzeń dla odzieży, biżuterii, akcesoriów i innych projektów unikatowych (341). MydlarniauFranciszka (189) i oui.pl (181) firma, która sprzedaje bieliznę przygotowała „zmysłowy kon-

\footnotetext{
${ }^{8}$ A. Ries, L. Ries, op. cit., s. 10.
} 
kurs”. Aktywne są także Koszulkowo.com, Answear.com, KsięgarniaKumiko.pl, StyloweButy.pl, bokado.p,chrum.com i 21Diamonds Polska. Ciekawy koncepcyjny układ zdjęć można zobaczyć na profilach pixers i 4max.pl (29). Natomiast w kategorii dom, nieruchomości i wyposażenie wnętrz swoje profile mają m.in. Bynaked.pl, Domiporta.pl, Dom i Ogród, Home Profit, Homplex.com, Manufaktura Pomysłu. Najwięcej osób, bo 541, śledzi konto Galerii DecoBazaar, która zajmuje się designem i sztuką użytkową. Na Pintereście można także znaleźć strony serwisów zakupów grupowych: Sweet Deal Polska, Groupon Polska i Scoupon. Obecne są tu także sieci sklepów stacjonarnych: The Body Shop Polska, Castorama Polska, Empik. Spośród fundacji, klubów, związków i stowarzyszeń na Pintereście działania prowadzą m.in.: Fundacja Anny Dymnej Mimo Wszystko (80 obserwujących) i CHI Polska. Na Pintereście można znaleźć wiele stron polskich firm związanych z marketingiem, branżą reklamową, PR. Najwięcej osób obserwuje profile: PRovoke (411 followersów), Think BIG (315), faceADDICTED Agency (257) i Harmonique PR (286). Możemy także obserwować konta powiązane z blogami Maltreting, Mediafun, socialmedia.pl czy Święta Dwójca oraz profil nowymarketing.pl (403). Bardzo aktywna jest też branża turystyczna. Miasto Gdańsk jest obserwowane przez 603 osób, a swoje konta mają tu także Gdynia, Sopot, Miasto Radom, Miasto Szczecin, Gmina Brody, Gmina Wielka Wieś oraz Foksal Residence, hotele Focus, Koneser, Piastowy Dwór z Jastrzębiej Góry czy serwisy HolidayCheck Polska, Grand Tour Poland i blog Podróżniccy9.

\section{Marka w odsłonie obrazkowej - przykład kreowania marki oraz angażowania społeczności w budowanie jej siły}

Pinterest jest wykorzystywany przez coraz to większą grupę polskich firm. Obecnie przeważają sklepy oferujące przedmioty atrakcyjne wizualnie, czyli np. butiki, sklepy jubilerskie, odzieżowe, wyposażenie wnętrz, ale silną pozycje mają również firmy, które świadczą usługi w obszarze mediów, marketingu, mody, urody, stylu życia. Na arenę wkraczają zakupy grupowe, nieruchomości fundacje, kluby związków i stowarzyszeń.

${ }^{9}$ http://pinterest.com [dostęp: 7.01.2013]; Czy warto zakładać konto na Pinterest? [Infografika], http://interaktywnie.com/biznes/artykuly/social-media/pinterest-jak-facebook-rosnie-w-polscerownie-szybko-23730 [dostęp: 5.01.2013]; Polskie marki na Pintereście - katalog Nowy Marketing, http://nowymarketing.pl/a/347,polskie-marki-na-pinterescie-katalog [dostęp: 28.08.2012]; http://pinterest.com [dostęp: 7.01.2013]. 
Dalej zaprezentowano analizę profilu firmy Winiary na Pintereście. Za kryteria analizy przyjęto wskazówki dobrego działania i prezentowania marki wśród społeczeństwa „obrazka”.

\section{Profil firmy Winiary na portalu Pinterest}

Jedną z pierwszych polskich firm, które zaczęły kreować swoją markę w nieco inny sposób była firma Winiary, która utworzyła profil na portalu Pinterest. Analizując profil Winiary na Pintereście można zauważyć, iż ta odsłona jest tworzona głównie w obrębie miłośników „smacznego i zdrowego gotowania”.

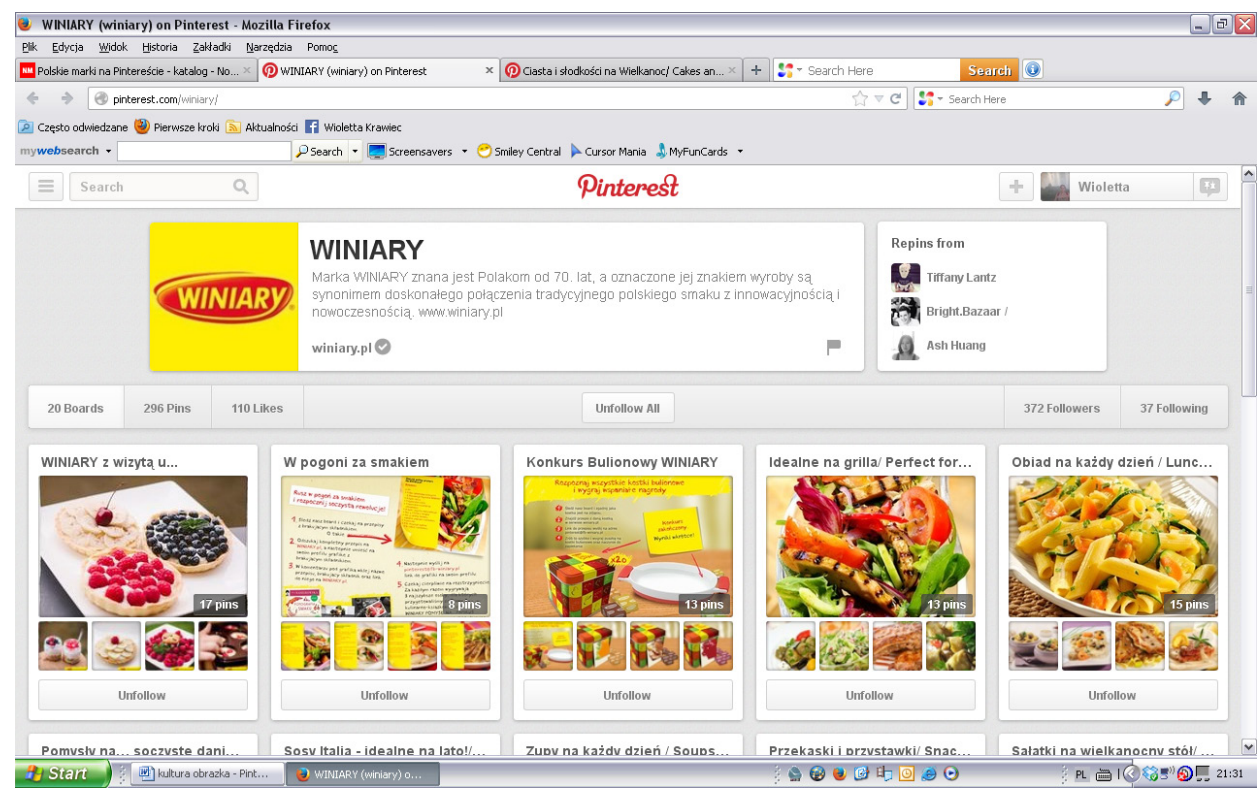

Fot. 1. Profil główny firmy na portalu Pinterest

Źródło: http://pinterest.com/winiary/ [dostęp: 4.09.2013].

Na wstępie należy zaznaczyć, że firma Winiary ma spójną strategię prezentacji na portalu Pinterest z własną stroną (www.winiary.pl). Jest to poprawne podejście w procesie budowania jednolitego postrzegania marki (firmy). Natomiast w tym artykule skoncentrowano uwagę wyłącznie na odsłonie tej marki na Pintereście. Pierwszą informacją, oprócz marki firmy, jest umieszczona zwięźle ogólna misja firmy: „Marka WINIARY znana jest Polakom od 70 lat, a oznaczone jej znakiem wyroby są synonimem doskonałego połączenia tradycyjnego polskiego smaku z innowacyjnością i nowoczesnością. www.winiary.pl". Jest to portal obra- 
zu, więc słuszne jest krótkie ujęcie, z przeniesieniem do strony www firmy, która ma, jak już wspomniałam, spójny wizerunek z portalem.

Na portalu firma umieściła 20 tablic tematycznych, w obrębie każdej z nich „przyczepione” zostały wątki, co powoduje, że występuje 296 przypinek (zdjęć). W obrębie tych przypinek pojawili się ich fani (110). Pozostałe statystyki profilu pozwalają określić grupę osób podążających śladami (śledzących) firmy, która w dniu analizy liczyła sobie 372 śledzących (followers). Natomiast oprócz ,śledzących” są również „następcy”, którzy mają swoje własne profile z podobną kulturą życia i inspiracjami (tzw. podążający za trendem). Statystyki podają, że podążających za trendem jest 37 (following), inspirują się oni marką i wdrażają ją w swoje odsłony na portalu i w życiu. Ich zaangażowanie wynika z pobudek osobistych lub zawodowych. W tab. 1 zaprezentowano tematykę tablic i liczbę przypiętych do nich zdjęć na profilu Winiary.

Firma Winiary, z wykorzystaniem swoich tablic, podkreśla rodzinny styl życia firmy i jej marki, koncentrując się głównie na różnych odsłonach dań, smaków i okoliczności, w których dane potrawy mogą być spożywane. To wszystko jest ładne, przyjazne i inspirujące. Na każdym kroku można odczuć, że nasi bliscy, członkowie naszych rodzin czy też nasi przyjaciele są bliskimi osobami dla marki Winiary, z którymi marka (firma) chce się spotykać i dzielić. Jeżeli mowa o rodzinie, to nie można też zapomnieć o ,świętach” swoich członków, dlatego m.in. na portalu można zaobserwować akcje ukierunkowane na Dzień Matki, Ojca, Dziecka czy też spotkania z przyjaciółmi na grillu itp. Najczęściej na tego typu spotkaniach tworzone są albumy fotografii, z którymi przez dłuższy czas nie możemy się rozstać opowiadając o miłych sytuacjach innym znajomym. Firma Winiary również na swojej odsłonie umieściła album pt. Spotkanie z przyjaciółmi WINIARY. $\mathrm{Z}$ punktu widzenia firmy jest to słuszne zachowanie, bo ludzie lubią dzielić się wspomnieniami, a to oznacza, że z marką Winiary spotka się znacznie więcej osób niż w czasie tworzenia albumu.

Tablice firmy Winiary, co potwierdza wyżej przedstawiona statystyka zarządzania 20 tablicami, są tematycznie ze sobą luźno powiązane. Dotyczą one np. aspektu kreowania smaków, które warto poznać, czy też wskazują nam dobrą porę na urządzenie grilla. Inne tablice dotyczą konkursów, spotkań itp. Wszystkie są skoncentrowane na gastronomi, ale każda z nich ma odmienny charakter. Zarządzając kilkoma tablicami, dajemy miłośnikom marki obszar wyboru miejsc, które ich najbardziej interesują. Przynosi to korzyści dla firmy, można zobaczyć, która z tablic przyciąga najwięcej fanów, co tak naprawdę trzyma ludzi przy marce i jakie czynniki mają największą siłę oddziaływania na śledzących portal. Patrząc chociażby na dane z tab. 1 można zauważyć, że największe zaangażowanie pojawiło się w obrębie Dnia Dziecka, spotkań z przyjaciółmi marki, Dniem Matki czy też inspiracjami ,wokół stołu”. Bacząc na fakt, że głównymi odbiorcami marki Winiary są kobiety, powyższe dane stają się wręcz oczywiste. Należy jednak 
zaznaczyć, że dzisiejsza kobieta jest osobą zapracowaną, ale również nastawioną na nowości i chcącą się rozwijać, dlatego też forma prezentacji, chociaż tradycyjnie pojmowanych, etapów życia kobiety nie może być banalna.

Tabela 1. Tablice Winary.pl - portal Pinterest

\begin{tabular}{|c|c|c|c|}
\hline \multirow{2}{*}{$\begin{array}{l}\text { Numer } \\
\text { tablicy }\end{array}$} & \multirow{2}{*}{ Tablica } & \multicolumn{2}{|c|}{ Liczba } \\
\hline & & przypinek & $\begin{array}{c}\text { osób } \\
\text { śledzących }\end{array}$ \\
\hline 1 & $\begin{array}{l}\text { WINIARY z wizytą u... } \\
\text { (Reporter WINIARY odwiedza kuchnie pasjonatów } \\
\text { gotowania! Oto jak smakowicie przebiegały nasze } \\
\text { spotkania! :) }\end{array}$ & 17 & 305 \\
\hline 2 & W pogoni za smakiem & 8 & 315 \\
\hline 3 & Konkurs Bulionowy WINIARY & 17 & 305 \\
\hline 4 & Idealne na grilla & 13 & 309 \\
\hline 5 & Obiad na każdy dzień & 15 & 311 \\
\hline 6 & Pomysły na... soczyste dania & 15 & 311 \\
\hline 7 & Sosy Italia - idealne na lato! & 15 & 308 \\
\hline 8 & Zupy na każdy dzień & 8 & 305 \\
\hline 9 & Przekąski i przystawki & 11 & 309 \\
\hline 10 & Sałatki na wielkanocny stół & 8 & 308 \\
\hline 11 & Pyszne świąteczne zupy & 17 & 309 \\
\hline 12 & Ciasta i słodkości na Wielkanoc & 12 & 311 \\
\hline 13 & Wielkanocne przepisy video & 14 & 304 \\
\hline 14 & Pyszne sałatki & 13 & 307 \\
\hline 15 & Wokół stołu - inspiracje & 19 & 316 \\
\hline 16 & Na Dzień Matki & 20 & 306 \\
\hline 17 & Na Dzień Dziecka & 30 & 306 \\
\hline 18 & Na Dzień Ojca & 19 & 316 \\
\hline 19 & Jak zrobić dobrego grilla? & 11 & 310 \\
\hline 20 & $\begin{array}{l}\text { Spotkanie Przyjaciół WINIARY - Przepiśniki } \\
\text { (W piątek, } 15 \text { marca } 2013 \text { odbyło się kolejne spotkanie } \\
\text { Przyjaciół WINIARY. Tym razem przygotowywali- } \\
\text { śmy... Przepiśniki! Zajrzycie do galerii i zobaczcie } \\
\text { nasze dzieła. :) }\end{array}$ & 26 & 305 \\
\hline
\end{tabular}

Źródło: opracowanie własne na podstawie danych z: http://pinterest.com/winiary/ [dostęp: 4.09.2013]. 
Pinterest umożliwia również śledzenie ruchów swojego fana i pozwala zebrać informacje o nim. Użytkownicy zazwyczaj śledzą przedmioty, miejsca, które lubią, jedzenie, które konsumują i rzeczy, które ich inspirują. Analizując profile swoich śledzących firma może zdobyć inspiracje do tworzenia nowych tabel tematycznych lub rozwoju firmy na nowych rynkach. Na przykład jedną z pierwszych „śledzących” odsłonę Winiary jest Pani Dominika. Na jej profilu umieszczonych jest 12 tablic tematycznych, które są zbieżne z zainteresowaniami Pani Dominiki. Tablice te odnoszą się do takich tematów, jak: inspiracje; produkty, które kocham; dla domu; sztuka; moda; fotografia; jedzenie, które kocham; infografika; social media; natura; mój świat czy też portfolio z obrazami. Przeglądając umieszczone tu tablice i podtablice można sądzić, że jest to osoba o dużej wrażliwości na piękno, które ją otacza. Sama jest artystką, tworzy własne dzieła, które - jak sama opisuje - są inspirowane naturą, pokazujące jej spojrzenie na świat (z przymrużeniem oka, nigdy „śmiertelnie” poważnie). Siłą przebicia jej sztuki jest siła koloru. Mając taką osobę za „fana”, firma wie, a przynajmniej powinna wiedzieć, że banalne rzeczy nie zatrzymają tej osoby „przy sobie”, a na pewno nie podzieli się ona własnymi wrażeniami ze swoimi znajomymi, bez różnicy czy w środowisku wirtualnym, czy rzeczywistym.

Firma Winiary pozwala swoim użytkownikom przypinać swoje zdjęcia czy komentarze do tablic. Jest to dobry sposób na budowanie wizerunku, jak również próba angażowania w kreowanie marki firmy we własnym stylu. Pogłębia to wiedzę o użytkowniku, ale również zwiększa percepcję marki. Mówiąc o angażowaniu użytkownika w życie marki należy organizować chociażby różnego typu akcje, np. konkursy, spotkania z miłośnikami gotowania. Ogłoszono chociażby konkurs pt. Konkurs Bulionowy WINIARY, w którego ramach niemalże codziennie umieszczane są krótkie zadania, np. pokazana jest na zdjęciu kostka przypraw firmy Winiary i po kolorze, kształcie, użytkownik ma zgadnąć, co to za smak czy też odnaleźć na stronie winiary.pl przepis na danie, w którym tę prezentowaną kostkę może użyć. Nagrodami są np. puszki na przyprawy. Chcąc zaangażować użytkownika w różnego rodzaju akcje należy mieć na uwadze, że tego typu konkursy muszą być łatwe, mało czasochłonne, ale przy tym zapewniające rozrywkę. Wówczas mamy szansę pozyskać kreatora i ambasadora marki. Angażować można również za pomocą „Spotkań z przyjaciółmi”, gdzie miłośnicy marki za pomocą kolorowego papieru, wstążek itp. opracowują „Przepiśnik". Oprócz tego, że uczestnicy spotkania zaangażowani są w wykonywane zadanie, to mają okazję poznać siebie w realnym świecie. Tego typu wydarzenia mają wpływ na wizerunek firmy, ale zarazem umacniają jej relacje ze swoimi fanami. 
Podsumowując, firma Winiary jest dobrym przykładem wykorzystania kultury obrazkowej w celu kreowania własnej marki. Jej odsłona może stanowić wzór do naśladowania dla innych firm, szczególnie tych (biorąc pod uwagę obecnych użytkowników portalu), których głównymi odbiorcami są kobiety.

\section{Zakończenie}

Wykorzystując infografikę wizualnie stymulujemy odbiorcę, wskazując mu nowe drogi myślenia i zwiększając jego świadomość marki i samoświadomość własnych twórczych możliwości. Dobrze opracowana infografika może przekazać więcej treści niż artykuł czy książka. Patrząc na infografikę, tak jak na obraz w muzeum, należy uwolnić własny umysł, wówczas dostrzeżemy to, co na pierwszy rzut oka jest mało widoczne lub wcale niewidoczne. Portal Pinterest jako pierwszy przyczynił się do pokazania marki w nieco inny sposób niż to było robione dotychczas, choć zachował podstawowe zasady kreowania marki w środowisku wirtualnym, tzn. opowiada jej historię, inspiruje konsumenta, wpływa na jego emocje, a w konsekwencji utrwalenie się w umyśle i wspiera proces podejmowania decyzji zakupowych. Ważne, aby firmy rozpoczynające kampanię w portalu o naturze obrazkowej miały swój pomysł na obecność w tym serwisie. Liczy się tu kreatywność oraz dedykowana i angażująca treść. Możliwości wirusowego wykorzystania Pinteresta są bardzo duże. Siła przyciągania tego portalu spowodowała już w Polsce lawinę klonów tego portalu, do których zaliczyć można: pisnpire.pl, zszywka.pl, pinka.pl, wstaw.pl i kilka innych.

\section{Bibliografia}

5 porad dla marek na Pinterest, http://social24.p1/5-porad-dla-marek-na-pinterest/ Czy warto zakładać konto na Pinterest? [Infografika], http://interaktywnie. com/biznes/artykuly/social-media/pinterest-jak-facebook-rosnie-w-polscerownie-szybko-23730

Dymkowska A., Promocja ładna jak z obrazka, „Marketing w Praktyce” 2012, nr 11

Jak używać Pinterest do wsparcia biznesu, http://www.conceptinteractive.pl/jakuzywac-pinterest-do-wsparcia-biznesu,blog,50,11,pl

Małecki M., Pinterest - czy polskie marki maja tu czego szukać?, http://nowymarketing.pl/a/28,pinterest-czy-polskie-marki-maja-tu-czego-szukac

Polskie marki na Pintereście - katalog, Nowy Marketing, http://nowymarketing. pl/a/347,polskie-marki-na-pinterescie-katalog 
Ratuszniak B., Pinterest jak Facebook. Rośnie w Polsce równie szybko, http:// interaktywnie.com/biznes/artykuly/social-media/pinterest-jak-facebookrosnie-w-polsce-rownie-szybko-23730

Raport: Pinterest nowym narzędziem marketingowym, www.oxmedia.pl

Ries A., Ries L., 11 praw budowania marek internetowych, IFC Press, Warszawa 2001

Schmidt B.H., Experiential Marketing, „Journal of Marketing Management” 1999, No 15

Zarys historii infografiki, http://infografika-polska.blogspot.com/2012_11_01_ archive.html

http://pinterest.com 